Section Editor

Mitchell S.V. Elkind, MD, MS

Nailyn Rasool, MD

Sashank Prasad, MD

Correspondence to

Dr. Rasool:

nailyn.rasool@gmail.com

Teaching NeuroImages:

\title{
Upright-supine test to evaluate vertical diplopia
}

Figure 1 Upright-supine test

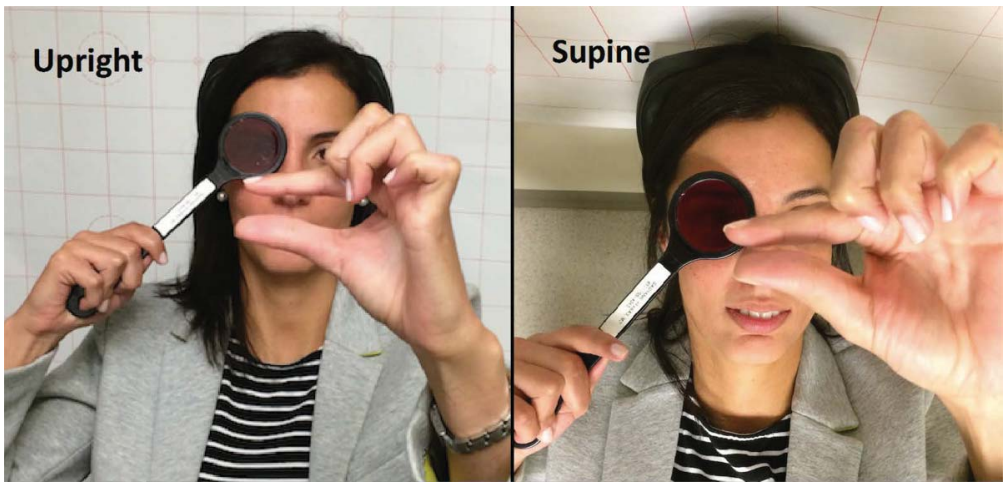

During Maddox rod testing, the patient used her fingers to demonstrate the separation of images. The vertical deviation decreased substantially (over 50\%) when supine compared to upright.

A 36-year-old woman presented with vertical diplopia, nausea, and disequilibrium. Maddox rod testing was performed in the upright and supine positions (figures 1 and 2).

Skew deviation is a vertical misalignment caused by a supranuclear lesion in the vertical vestibuloocular reflex pathways, including the vestibular nerve, brainstem, or cerebellum. It arises from perturbed utricular inputs, and the amplitude of the ocular deviation is therefore sensitive to gravitational forces. ${ }^{1}$ The upright-supine test helps localize the cause of vertical diplopia by distinguishing skew deviation from infranuclear causes. ${ }^{2}$ With skew deviation, the vertical deviation is substantially reduced when the patient is supine, whereas with infranuclear lesions it is not.

\section{AUTHOR CONTRIBUTIONS}

Nailyn Rasool: drafting/revising the manuscript, study concept or design, analysis or interpretation of data, accepts responsibility for conduct of research and final approval. Sashank Prasad: drafting/revising the manuscript, study concept or design, analysis or interpretation of data, accepts responsibility for conduct of research and final approval, study supervision.
Figure 2 MRI brain (axial fluid-attenuated inversion recovery)

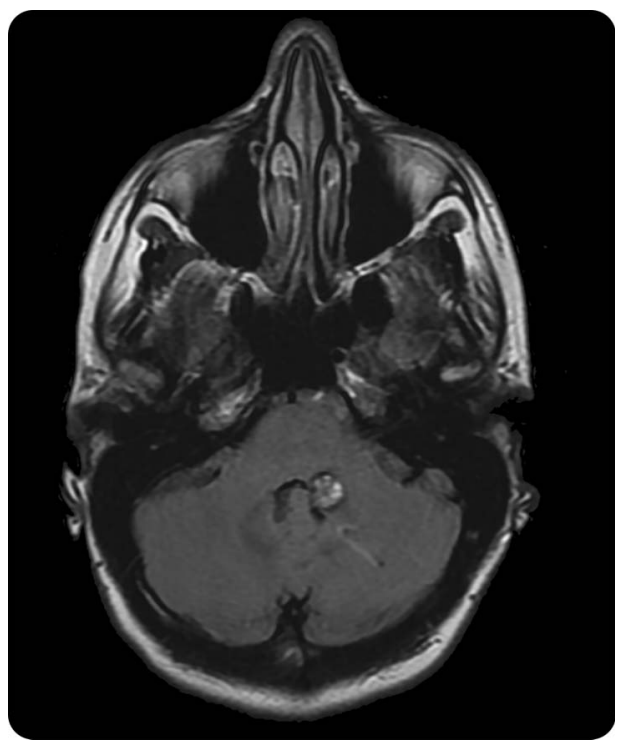

Axial fluid-attenuated inversion recovery MRI demonstrates heterogeneous hyperintensity with a rim of hypointensity, suggestive of a cavernous malformation in the left middle cerebellar peduncle.
Download teaching slides: Neurology.org
From Massachusetts Eye and Ear Infirmary (N.R.) and Brigham and Women's Hospital (N.R., S.P.), Harvard Medical School, Boston, MA. Go to Neurology.org for full disclosures. Funding information and disclosures deemed relevant by the authors, if any, are provided at the end of the article. 
STUDY FUNDING

No targeted funding reported.

\section{DISCLOSURE}

The authors report no disclosures relevant to the manuscript. Go to Neurology.org for full disclosures.

\section{REFERENCES}

1. Suzuki JI, Tokumasu K, Goto K. Eye movements from single utricular nerve stimulation in the cat. Acta Otolaryngol 1969;68:350-362.

2. Wong AM, Colpa L, Chandrakumar M. Ability of an uprightsupine test to differentiate skew deviation from other vertical strabismus causes. Arch Ophthalmol 2011;129:1570-1575. 


\title{
Neurology
}

\author{
Teaching NeuroImages: Upright-supine test to evaluate vertical diplopia \\ Nailyn Rasool and Sashank Prasad \\ Neurology 2015;84;e153-e154 \\ DOI 10.1212/WNL.0000000000001569
}

This information is current as of May 11, 2015

Updated Information \&
Services
Supplementary Material

References

Subspecialty Collections

Permissions \& Licensing

Reprints including high resolution figures, can be found at: http://n.neurology.org/content/84/19/e153.full

Supplementary material can be found at: http://n.neurology.org/content/suppl/2015/05/09/WNL.0000000000001 569.DC1

This article cites 2 articles, 0 of which you can access for free at: http://n.neurology.org/content/84/19/e153.full\#ref-list-1

This article, along with others on similar topics, appears in the following collection(s):

All Clinical Neurology

http://n.neurology.org/cgi/collection/all_clinical_neurology

All Neuro-ophthalmology

http://n.neurology.org/cgi/collection/all_neuroophthalmology

Arteriovenous malformation

http://n.neurology.org/cgi/collection/arteriovenous_malformation

Diplopia (double vision)

http://n.neurology.org/cgi/collection/diplopia_double_vision

Ocular motility

http://n.neurology.org/cgi/collection/ocular_motility

Information about reproducing this article in parts (figures,tables) or in its entirety can be found online at:

http://www.neurology.org/about/about_the_journal\#permissions

Information about ordering reprints can be found online:

http://n.neurology.org/subscribers/advertise

Neurology ${ }^{\circledR}$ is the official journal of the American Academy of Neurology. Published continuously since 1951, it is now a weekly with 48 issues per year. Copyright (C 2015 American Academy of Neurology. All rights reserved. Print ISSN: 0028-3878. Online ISSN: 1526-632X.

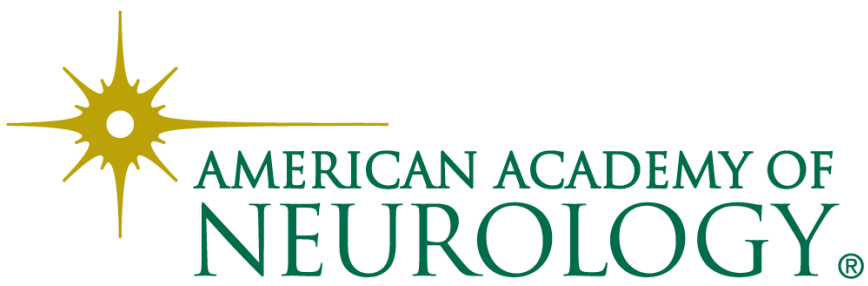

